\title{
Geopolitics Taking the Signature from the Russian-Estonian Border Treaty (2005)
}

\author{
Toomas Alatalu \\ Institute of Political Science and Governance, \\ Tallinn University \\ Narva mnt 25, \\ Tallinn 10120, Estonia \\ E-mail: talatalu@online.ee
}

Abstract: Explaining the withdrawal of his signature from the EstonianRussian Border Agreement, the Minister of Foreign Affairs Sergey Lavrov announced on June 27, 2005 that "they in the EU might have succumbed to the temptation of telling us to ratify it [...] on your side also, with some interpretations attached, so that the treaty can enter into force. To stop the EU from falling into this temptation, we have withdrawn our signature. There will be no treaty". Thus, Moscow actually punished the European Union, which seems logical as with regard to geopolitics and geostrategy, the border negotiations were held in the buffer zone between the European Union and Russia.

In 2004-2005 Russia held simultaneous and also interconnected border negotiations with Japan, China, Kazakhstan, Latvia and Estonia, with agreements eventually signed only with China and Kazakhstan. Failures with Japan, Latvia and Estonia derived from Moscow's position to keep all gains of World War II. At the same time Russia had related all its foreign affairs with the celebration of the $60^{\text {th }}$ anniversary of the end of World War II held in Russia, which was curiously used by the young Georgian leader Mikheil Saakashvili, whose quick and clear manoeuvres approved by the West turned the ordinary Rimland country Georgia into a classic geopolitical pivot. And all this was done at the expense of Russia's influence. The highlight of the process was Saakashvili's statement that he will come to Moscow on May $9^{\text {th }}$ only if Russia agrees to withdraw its military bases from Georgia. The Kremlin considered it best to agree, however, as the European Council aside the US, uniting the problems of Estonia, Latvia and the non-EU member Georgia, also began to praise the latter for overcoming Russia, Moscow decided to punish the nearest available EU member in the given situation by withdrawing its signature from the Russian-Estonian border treaty. 
Keywords: buffer state, soft buffer, Estonian-Russian border treaty, geopolitical pivot and re-orientation geopolitics, geopolitics in EU-Russian relations, Georgia's revolutionary invasion to world policy-making, geostrategy, Russia's simultaneous handling of five border treaties

\section{Introduction}

The birth and signing of the Russian-Estonian border treaty by Ministers of Foreign Affairs Urmas Paet and Sergey Lavrov in Moscow on May 18, 2005 was a long-awaited event in terms of the relations between the two states and also between Russia and the EU, which Estonia had joined only a year earlier (on May 1, 2004). Thus it was all the more surprising to learn on June 22, 2005 of Russia's decision to withdraw Lavrov's signature from the treaty, that is, to revoke it, as Russia could not agree with the wording of the preamble in the statute declaring the ratification of the treaty by the Estonian Parliament on June 20, 2005. More specifically, with the facts included in the documents mentioned in the preamble. Russia's decision was all the more surprising as in international relations there had been no previous cases in which a treaty had been revoked by withdrawing the signature. On the other hand, it was commonly understood that by accusing the Estonian legislative body for the preamble of the law, Moscow did not punish the latter-it would have been far easier for the State Duma to refuse to ratify the agreement on their behalf or to revoke it-but the Estonian government and the Ministry of Foreign Affairs who had conducted all procedures as required, confirmed also (for two months) by Lavrov's signature. Naturally, also the State Duma had the right to make a statement at the time of ratification, the right that the Russian Parliament has repeatedly used before and after June 20,2005. It should also be noted that the issue of the possible State Duma statement was discussed by none other than its Chairman of the Committee for Foreign Affairs Konstantin Kosachev on June 20, 2005 (Socor, 2005f). Furthermore, in his interview to Estonian daily Postimees, the man with the experience of the negotiations between Russia and Japan claimed that the lawyers were "now" (as the Kremlin had conclusively dismissed the agreement on September 1) arguing whether the wording of the ratification law included territorial demands and clearly declared it a political issue (Sildam, 2005).

Why did Moscow decide to punish the Estonian government instead of the Parliament? In our opinion, the key to the answer lies in the statement made by Sergey Lavrov on June 27, 2005 in Helsinki. While explaining the punishment 
of Estonia or the withdrawal of his signature from the border treaty at the press conference, Lavrov turned the whole issue against the European Union:

They in the EU might have succumbed to the temptation of telling us, well, Estonia has ratified it, even if adding references to 'occupation', 'aggression', 'unlawful annexation', but ratified it anyway [...] so please show a bit of patience and ratify it on your side, also with some interpretations attached, so that the treaty can enter into force. To stop the EU from falling into this temptation, we have withdrawn our signature. There will be no treaty. (Socor, 2005f; Levinsson, 2006, p. 107; PBK, Interfax News Agency, RIA Novosti, 27-28 June 2005)

It is obvious that the Minister of Foreign Affairs of the great power explained the situation with reference to geopolitics and the detailed analysis of the events from May to June 2005 (see Alatalu, 2012a) leaves no doubt about it. And all of this in terms of both the competition between the two great powers and geostrategic players Russia and European Union and also Estonia as the buffer state. In case of the latter, Russia as the buffering side reacted to-in Kremlin's opinion - the excessive growth of the influence of the opposing side in the buffer zone, which at one point exceeded the borders of Estonia and Latvia, as Moscow considered also a third state - Georgia, which shall be further analysed below-among them, which the European Union had unexpectedly set next to Estonia and Latvia and discussed them together at the EU summit.

In the geopolitical discussions of Russian foreign affairs, the analysts have been able to distinguish it from its neighbours (heartland, separate civilisation) and describe the vicinity (borderland, outer crescent and inner crescent, intermediate zones, spheres of influence, etc.); however, they usually do not notice the fact despite its enormous borderline (20,241 km of land frontier with 14 neighbours). Moscow is still able to implement the same policy with respect to the various small neighbours. On June 22, 2005 (the same day that Moscow said "no" to the border treaty with Estonia, see above), the Parliamentary Assembly of the Council of Europe got Russia's assurance to "denounce as wrong the concept of two different categories of foreign countries, whereby some are treated as a zone of special influence called 'the near abroad"'. This was considered as the new concept of Russian foreign policy (July 2008) and the national security concept (May 2009) no longer mentioned 'the near abroad', however, the Russian leaders nevertheless continued to use the given term and also 'zones of influence' and even coined a new concept of 'privileged interests' (Council of Europe Parliamentary Assembly, 2012, points 131-137) both on the grounds of 
the Russian-Georgian war and with regard to the lexicon of other geostrategic players.

In addition to its extensiveness, the Russian foreign policy is also rather traditional thus facilitating its analysis. For instance, it was not difficult to notice that turning Southern Ossetia and Abkhazia into the $15^{\text {th }}$ and $16^{\text {th }}$ 'neighbouring countries' (from Moscow's point of view) in 2008 proceeded analogously to the sequence of events in 1939-1940 in West Belarus, West Ukraine, Finland (discontinued due to the disappearance of the Finnish Democratic Republic), Estonia, Latvia, Lithuania, Moldova and in 1944 in the Tuvan People's Republic (Alatalu, 2012b, pp. 25-27).

It was certainly one of the major news of the $21^{\text {st }}$ century that in 2004-2005 the great power Russia took the initiative to solve its border issues simultaneously with Estonia, Latvia, Kazakhstan, China and Japan - a fact that apart from the present author has not been discussed by anyone tackling the border questions of Estonia/Latvia and Russia. The context was never mentioned while the topic was discussed in Estonia from December 2004 to June 2005. However, it was even suggested in the study commissioned in relation to the border treaty that

Estonia should abandon bilateral relations with Russia at the highest political level. The communication relevant to Estonian statehood should be conducted through the European Union, whereas the determination of the rules for the Estonian-Russian relations should be mediated by the EU institutions on the basis of EU policies. (Made, 2005, p. 104)

Also afterwards, the behaviour of Estonia and Latvia has been evaluated on the basis of their EU membership and in the context of the relations between the EU and Russia with the attempt to depict the situation as if all decisions were made in Brussels and not in Tallinn and Riga (Made, 2006; Nutt, 2011, pp. 167-177; Rostoks, 2006; Ozolina, 2008). In other words, in case of Estonia and Latvia the individual's relation with the great power is considered, whereas in case of Russia it is pretended, for instance, that the fate of the Estonian-Russian border treaty was not influenced by Moscow's simultaneous talks on the fate of the islands with Japan or the border treaty between China and Russia, which is an obvious misconception. Moscow's problems concerning the borders with Japan, Estonia and Latvia emerged as a result of World War II, which Russia never forgot, starting from Vladimir Putin's opening from a position of advantage at his first border talks with Japan on the results of the war during his presidency that were directly related to the cancellation of the border treaty with Estonia (see above). 
While after their accession to the EU and NATO, it was impossible to picture other East-European countries in Moscow's sphere of influence or as buffer states, the situation with Estonia and Latvia was and still is somewhat different due to the changes in the ethnic composition of the population during the period of occupation. In fact, by the time the buffering countries Germany and the Soviet Union began their mutual assistance, it was precisely the Baltic States that had acquired the classic characteristics of a buffer state during the period between the two world wars (Turmanidze, 2009, pp. 1-11). The 'division of tasks' between the two totalitarian states reached its culmination as the former forced Latvia and Estonia into cooperation (see the non-aggression pacts between Latvia-Russia and Estonia-Russia, June 7, 1939) in order to allow the latter to accuse them of the selfsame cooperation in its infamous subsequent ultimatums (see the Soviet ultimatums to Estonia and Latvia, June 16, 1940).

The period of the restoration of the independence of the Baltic countries coincides with the clear attempts to turn them into buffer states again considering the two unilateral and multilateral security guarantee offers made by Russia in 1997. Such offers were decisively ended by the signing of the US-Baltic Charter on January 16, 1998 in Washington establishing the partnership between the world's greatest power and Estonia, Latvia and Lithuania. The charter did not include security guarantees to the Baltic States by the US but highlighted the interest and permanent political presence of the US in the region. It could be seen as a manifestation of the so-called soft power in the form of a soft buffer. More precisely, the traditional hard buffer politics of Russia (accusations, demands, etc.) was balanced by the soft buffer, i.e. by the US-Baltic Charter. As Estonia, Latvia, Lithuania and others soon joined NATO, the given situation turned out to be a temporary phenomenon. However, only formally so, as in reality Russia retained the ability to influence the course of events in Latvia and Estonia and hence also the whole political course of the EU with the help of the local Russian-speaking population. And as long as Russia can impose its will in Latvia and Estonia by means of its compatriots, we may still talk about the buffer zone on the eastern coast of the Baltic Sea.

In fact, having joined the EU together with Estonia, Latvia and Lithuania, also Cyprus remained a buffer zone between the EU and Russia, which — differently from the Baltic zone - has clearly paralysed the European Neighbourhood Policy and turned into the Trojan horse of the EU banking policy. 


\section{Moscow's chessboard for five neighbours}

When starting to solve the border issues with five neighbours of various historical background and various weight class, Moscow had to consider the fact that not all talks could yield equally successful results nor was there a guaranteed winwin situation, and thus they had to be prepared for certain losses. Naturally, they also weighed the options for compensating for the losses that could threaten those remaining the last before the completion of the five-member process.

It may already be stated that it was Estonia who 'managed' to be the last among the five parties mentioned above both due to tiffs in its domestic policy (there were two coalitions and three Ministers of Foreign Affairs between February and April 2005), short-sighted foreign policy (lack of cooperation in the border treaty issues between Estonia and Latvia) and the foreign policy manoeuvres displeasing Moscow (the meeting between President Arnold Rüütel and Vladimir Putin in Moscow on January 20 and the announcement on March 7 of the nonattendance of the celebrations on May 9 in Moscow, the establishment of the "New Friends of Georgia" group initiated by the Minister of Foreign Affairs Kristiina Ojuland on February 4, and the decision not to give the foreign affairs ministerial post to the Centre Party (Keskerakond) who had signed a cooperation agreement with United Russia) (Alatalu, 2012a, pp. 18-25).

Although the official and public world politics agenda had included the signing of border treaties between both Estonia-Russia and Latvia-Russia since December 2004, the home truth is that in February-April 2005 Moscow only had talks with Riga. These were brought to an abrupt end by Moscow on April 26 and 29, 2005, followed by a week of silence, and only then, on May 4, did Estonia receive the invitation to come to Moscow to sign the treaty, which eventually took place on May 18, 2005. It may be considered symbolic that two days later, on May 20 , the State Duma ratified with 307 affirmative votes (by the ruling party) and 80 negative votes the border treaty between Russia and China that had caused long-term tension due to the territorial concessions. The dissatisfied parties thus required appeasement.

The need for solving the border issues simultaneously with five states was due to the development of world politics following the Cold War period. The withdrawal of Russian troops from Germany and the Baltic States opened the gates for the joining of the Eastern Europe with the rest of Europe and thus also for the arrival of NATO and the European Union to Russian borders. The given decision was made in 1994 and executed in 1997; however, ignoring the agreement between 
the teams of Bill Clinton and Boris Yeltsin, on April 2, 1996 Moscow began the establishment of the Union State of Russia and Belarus, in other words, it was Russia who first made a proactive move towards the West. Soon a step towards Asia followed - the foundation for the Shanghai Cooperation Organisation was established on April 16, 1996, directly influencing the emergence of the topic of the border talks between Russia-China and Russia-Kazakhstan on the agenda.

By continuously reacting to the advancement of the EU and NATO towards the East (initiating the summits between France, Germany and Russia in March 1998, etc.), Moscow quickly began developing its relations with China, India and Japan in 1997 and 1998. The given course was clearly continued by Vladimir Putin after receiving the full power of Russia on the New Year's Eve of 2000. His plans for the restoration of the great power force included the regulation of the problems with relevant neighbours starting with Japan where President Putin arrived on September 3, 2000 (the visit was delayed by a week at the last minute), following the wreath-laying ceremony in the morning in Yuzhno-Sakhalinsk at the local " $50^{\text {th }}$ anniversary celebrations of the liberation from Japan".

The curious psychological attack was followed by Putin's assurance to the Japanese Prime Minister Yoshiro Mori to implement the assertions of the declaration of October 19, 1956 between the Soviet Union and Japan saying that subsequent to the signing of the peace treaty, Moscow would be willing to discuss the "ceding" of two (of the four occupied) islands (South Kuril Islands in Russian terminology, the Northern Territories in Japanese). The given assurance was considered a breakthrough in the Russian-Japanese relations (Rozman, 2002 , pp. 338, 341), as despite no changes in the territorial borders, following his premiership (2000-2001), Mori received special authorisation from the next governments to enhance the Japanese production export potential to Russia with its first victory including the commencement of operation of the Toyota car factory near St Petersburg on June 14, 2005, that is, during the events of the main concern of the present article. Three months later-on September 7, 2005-the construction of Nord Stream was announced in St Petersburg, demonstrating that Russian foreign policy had had simultaneous success in Asia and Europe.

Immediately following the arrival of the EU and NATO at the Russian borders, Moscow made a radical move in its relations with China-on his visit to Beijing on October 14, 2004, Putin signed the (first) border treaty with China the ratification of which on May 20, 2005 was already mentioned above (the second treaty relating to the western part of the mutual border was signed on July 22, 2008). Commenting on the treaty, Foreign Minister Lavrov stated that the disputed 375 square kilometres had been divided equally, whereas the Chinese 
confirmed receiving 337 square kilometres (International Herald Tribune, 22-23 January 2005). If most of the islands in the border rivers were halved, China was granted the control of two of the islands Yinlong (Tarabarov) and Zhenbao in their entirety.

This marked an essential change in the behaviour of the Russian leaders, since so far they had insisted on not giving anything to anybody. In these parts of Europe, for instance, Boris Yeltsin's words are well remembered, as he stated on November 23, 1994 while constructing a border post on the Estonian-Russian border, "Russia shall not give up one single centimetre of sacred Russian land no matter who covets it" (New York Times, 24 November 1994).

The emergence of the issue of "two islands" in Beijing naturally got the Japanese's hopes up; however, it eventually turned out to be a clever manoeuvre by the Kremlin. On November 20, 2004, at the APEC summit in Santiago de Chile, the new Japanese Prime Minister Junichiro Koizumi got a brief assurance from Putin that Russia was continually interested in solving the given problem. The experts of both countries met on February 2, 2005 to discuss the various options (including the possibility that Japan give up three islands in order to get the largest island that had not been "promised") (Takahashi, 2005). Putin received an invitation to Japan for March (related to the opening of EXPO2005), but visited the country only on November 20-22, 2005 to thank the Japanese for establishing the car factory and leave the fate of the islands unresolved (which has remained so until present). Prior to Putin's arrival, on November 17, the results of the public opinion poll were published, according to which 67 per cent of Russians, that is 20 per cent more than in 1999 opposed to the return of the islands to Japan (Masaki, 2005). It is worth mentioning that the given opinion poll was organised after ceding the island(s) to China and accusing Estonia of territorial claims in justifying the withdrawal of the Russian signature from the border treaty.

The results of the given poll were also reflected in the ratification of the Russia-Kazakhstan border treaty in the State Duma on November 16, 2005 with 312 affirmative votes, 47 negative votes and 2 neutral votes. The border talks with Kazakhstan had similarly been long with nationalists and Vladimir Zhirinovsky's party demanding the annexation of the so-called virgin lands to Russia. In January 2004, the presidents Vladimir Putin and Nursultan Nazarbayev announced the plan of accelerating the negotiation process which was clearly actuated by the agreements reached in May 2003 in St Petersburg to expand the EU-Russian relations weakened by the open borders in the east, from the EU perspective, especially with Kazakhstan (Central Asia). The text was promptly composed and the border treaty signed in Moscow on January 18, 
2005. The Kazakh opposition organised several protests. The lower house of the Kazakh Parliament, Majilis, ratified the border treaty without any negative votes similarly on November 16, 2005-a fact reminding of the offer made to Estonian MPs by the State Duma Chairman of the Committee for Foreign Affairs Konstantin Kosachev in February 2005 about the parallel discussion and ratification of the future border treaty (Riigikogu transcripts, 2005, p. 1505) that everybody (?) somehow managed to forget.

Following the steps and compromises in Asia, that is, securing the rear, Moscow finally turned to face Europe. Keeping to his assurance to the EU on April 27, 2004 (the EU-Russian joint commitment agreed without the inclusion of the Baltic States, who had not yet joined the EU to "ensure the defence of the rights of the minorities"), Putin confirmed at the EU-Russia summit on November 24, 2004 his willingness to sign the border treaties with Estonia and Latvia. On December 2004, the latter were sent Moscow's formal confirmation and the texts of bilateral "Political declaration on the foundations of relations" to be signed together with the border treaties. In other words, it had been Moscow's idea to add something to the border treaty.

The attitude to the appendix immediately brought out the differences in the Latvian and Estonian tactics - following the publication of all offered documents on the website of the Russian Ministry of Foreign Affairs on February 1, 2005, Latvia published their own variation of the declaration on February 11, whereas the Estonian Ministry of Foreign Affairs claimed that it does "not consider the declaration to be necessary" (The Baltic Times, 2005). Unfortunately, with the release of Minister Kristiina Ojuland from office (February 10), a period of political confusion followed in Estonia-for two weeks there was no Minister of Foreign Affairs, followed by the coalition crisis and the formation of new government and thus Russia could only negotiate with Latvia. The given talks were completed and the day for signing the treaty set on May 10 (the day of the new EU-Russia summit). On April 26, the Latvian government announced that due to the discrepancies in the constitution and the border treaty, a declaration will be issued related to the signing of the treaty (for explanations see European Commission, 2006), to which Moscow replied by discontinuing the whole process. It was stated in the announcement by the Russian Ministry of Foreign Affairs that in addition to Latvia it also concerns "a number of their allies in the EU and NATO" (Russian MFA, 2005). Latvia received the official refusal on April 29 after Foreign Minister Lavrov's phone calls (on his visit to Israel with Putin) to the US Secretary of State and the European Commissioner for External Relations with the latter considering the situation a bilateral problem, that is, of both Latvia and Russia (Socor, 2005b). 
As Estonia, left idle, continued to signal of its willingness to sign the border treaty and both sides needed positive reports at the EU-Russia summit, on May 4 Estonia received the invitation to come to Moscow to sign the treaty on May 18. It was a delicate situation-following the public refusal of one Baltic state, masterminded in a peculiar and heated international situation (Will you come to Moscow on May $9^{\text {th }}$ to celebrate Russia's victory or not?), the signing of a similar treaty was offered to its neighbour. As there are no choices for small countries in big politics, Estonia promptly agreed and the treaty was signed.

The border treaty was ratified in the Parliament with similar haste, despite all parliamentary factions stating on the first day that it would be "postponed until autumn" (see Kagge, 2005). Nevertheless, the Foreign Affairs Committee initiated the ratification process already on May 30 with the final vote taken three weeks later.

Estonia understandably acted in haste and under external pressure. Such advice was given by the US Department of State, the High Representative of the Union for Foreign Affairs and Security Policy Javier Solana, the European Commissioner for External Relations Benita Ferrero-Waldner, and others (Socor, 2005c), and confirmed also by the Estonian Foreign Minister Urmas Paet appearing before the Parliament (Riigikogu transcripts, 2005, pp. 1365, 1507). This demonstrates that Estonia was clearly positioned on a geostrategic playground. It is never easy for a small state to enter into a border treaty with a great neighbouring country, all the more so in a situation in which influential political allies in the Transatlantic space put further pressure on it to ensure their own good relations with the given great power, that is, with Russia. It is unlikely that Estonia was deliberately placed on the firing line; however, it is obvious that those shaping the EU and US foreign political decisions cannot always foresee the impact of their decisions on Russia's behaviour.

\section{The subsequent facts}

The behaviour of Moscow is traditionally considered unpredictable, which, however, is only partially true, as in most cases it is either a proactive or subsequent excuse for the insufficiently considered decisions and actions. In fact the logic was simple - the more the leading figures of the West attached themselves to the signing and ratification of the Russian-Estonian border treaty, especially after Moscow's withdrawal from the Russian-Latvian border treaty, the more they would suffer by the second failure of the same process. In big 
politics, the little victories taken in the name of geostrategy, that is, the victories at the expense of small states, could sometimes be rather sweet. Not having the power to stand up against the European Union as a whole, Moscow is still capable of hurting some of the small states in a sensitive location, especially if the situation is further enhanced by the unexpected and surprising change of mind by the EU leaders.

In addition, the western experts, stuck in the traditional schemes, most probably could not evaluate sufficiently and fast enough the new aspects provided by the unexpected emergence of the Georgian (then) revolutionary leader Mikheil Saakashvili on the joint geostrategic playground against all theories and perceptions. It came as a surprise to the leaders of Russia, US and the European Union.

The Presidency Conclusions of the Council of the European Union held on June 16-17, 2005 included four points dedicated to the Russian policy. The latter two were dedicated to Russian relations with the Baltic States and Georgia:

61. The European Council welcomes the signing of the border agreement between Russia and Estonia and hopes that a similar agreement can soon be signed with Latvia.

62. The European Council also welcomes Russia's commitment to complete the evacuation of the remaining Russian military bases in Georgia in the course of 2008. It expects the full implementation of all commitments entered into in Istanbul in 1999. (European Council, 2005)

It all becomes clear when comparing the statements with the conclusions made by the European Council a year before on June 17-18, 2004, welcoming Armenia, Azerbaijan and Georgia in the European Neighbourhood Policy (Section 66) separately from their relations with Russia. Section 76 dedicated to the latter, however, "welcomes the Russian government's commitment to early signature and ratification of agreements on Russia's borders with Estonia and Latvia" (European Council, 2004). Since in both documents the section on Russia begins with the reference to the EU-Russian summits - on May 10, 2005 and May 21, 2004 , respectively - it is worth noting the disappearance of the 'ratification' in the decisive year from the official document issued solely by the EU and not as a joint document by the EU and Russia or merely by Russia. The European Council conclusions (2005) were mentioned in the Foreign Minister Urmas Paet's article on the day of ratification and in his appearance before the Parliament; however, not in connection with the detail (from 2004 conclusions) highlighted in the said article (Postimees, 2005; Riigikogu transcripts, 2005, p. 1567). 
Considering also other signals of threat received at the time about the behaviour of the European Commission (Socor, 2005e), it may be concluded that Estonia and its parliament actually took a serious risk on June 20-something that was not known or even acknowledged. Comparing the documents of the two summits, logical questions arise: Did the European Union know that there would be no ratification? Or that Estonia would be made to wait for Latvia? Then again, as already members of the EU and thus with an access to the writing of Presidency Conclusions, why did not Estonian and Latvian representatives point out the disappearance of 'ratification' from the text? Furthermore, they must have understood the signal given to Moscow by leaving out 'ratification' from the EU top document at the eleventh hour?

It must be stated that the preparation of the border treaties between Latvia-Russia and Estonia-Russia in 2004 and 2005 was not the best time for the European Union, considering the development of new mutual relations between the great powers and the revolutions in Georgia and Ukraine. The uncertainty resulting from the expansion with a "big bang" was fuelled by a new political crisis, reaching its culmination with the rejection of the new EU constitution in France and Holland (on May 29 and June 1, 2005). By regulating the border issues with Japan, China and Kazakhstan, Russia, on the other hand, had acquired valuable experience in negotiating with two small states and their backers.

Judging by the records and the related documents of the General Affairs and External Relations Council meeting on July 18, 2005 in Brussels, the EU leaders' perception of the relations between Russia and Latvia-Estonia in the situation makes one shrug in disbelief. The text is naturally brief - according to the GAERC document, Urmas Paet talked about the signing of the border agreement at the end of the meeting "in the light of recent announcements by Russia regarding a decision not to present the agreement for ratification" and the Latvian Minister of Foreign Affairs explained the situation of their border treaty to which the EU Foreign Ministers "expressed support for the position of Estonia and Latvia in seeking ratification of their border agreements" (European Council meeting, 2005). Is that all? Accounts of the given meeting in the official publication of the Estonian Ministry of Foreign Affairs Estonian Review suggest that Paet thanked his colleagues for their support and declared the signing of the border treaty "a collective EU achievement. This is a good example of achieving a desired result when speaking with one voice." Paet assured that the ratification of the border treaty is "in the mutual interests of all of us-Estonia, Russia and the EU". And it was followed by a discussion of other topics. Analogous Latvian publication Current Latvia offers a surprise-following Urmas Paet's statements on the ratification and Artis Pabriks's overview of the state of their border treaty, the EU 
Council, Javier Solana, and Benita Ferrero-Waldner "expressed their full support and understanding of this issue to Latvia and Estonia, noting that, regardless of their different approaches to dealing with the border treaties, both Latvia and Estonia are currently in identical positions" with no improvement in the near future, but the EU shall continue to monitor the issue of both border treaties (Current Latvia, 2005). No suggestion was made to anything depending on Russia or to anyone attempting to speak to Moscow. It seems that the EU leaders merely agreed with Lavrov—not only will there be no signatures on the Russian-Latvian border treaty, there will be no Estonian-Russian border treaty either.

\section{Georgia-the geopolitical and geostrategic pivot}

Revisiting the documents of the two EU summits, the issues related to Georgia were not brought up by coincidence. It may be stated that the courage escaping the EU leaders in giving evaluation to the Estonian and Latvian situation-after all, 'ratification' did disappear-was well evident in praising the newcomer Georgia for the latter's defeat of Russia. And all this with "hope for the complete execution" of all the obligations assumed by Russia in 1999, that is, considering the elimination of the military bases in Moldova. While in the case of Latvia and Estonia the EU leaders avoided the naming of Russia, then in the case of Georgia the declaration clearly sounded like picking a quarrel. In addition, the statements made about the Member States Estonia and Latvia and the nonmember Georgia in the document of the EU summit 2005 were next to each other and syntactically related. Thus it may be said that the European Union openly encouraged that the "Russian-Latvian/Estonian border treaties in the context of Russian-EU relations" become "Russian-Latvian/Estonian/Georgian relations in the context of Russian-EU relations". It was mentioned above that Moscow hardly left the disappearance of 'ratification' unnoticed and the same applies to the presentation of the new set of states. It is also certain that if Moscow was irritated by anything at all, it was the new group of states and the EU and US praise of Georgia's behaviour.

In geopolitical sense, Georgia had actually taken an incredible leap from the periphery to what could be called a geopolitical pivot. And primarily thanks to the West's insufficient knowledge of the former Soviet Union and also to the wishes prevailing in the second half of the 1990s in some of the great power capitals to retain Moscow's free hand in regions that the latter traditionally considered as its areas of influence. 
As far as Georgia's earlier courses of development are concerned, let us not forget that similarly to the Baltic States the land of highlanders was a pain in the Kremlin's neck in 1989 and 1991, and when considering the interim revocation of the Independence of Lithuania (May 1990 to July 1991), it was actually the Republic of Georgia who was the first to declare its independence on April 9, 1991 (prior to the August Coup in 1991). The return to power of the former KGB and Communist Party leader Eduard Shevardnadze left Georgia related to Moscow, and despite the parliament's numerous attempts to get rid of the Russian military forces based in Abkhazia, South Ossetia and the so-called authentic Georgian territories, Shevardnadze managed to control the situation. The external support in the form of the "Friends of Georgia" (including France, Germany, UK, US, Russia), established by the western great powers in 1993, acknowledged also Shevardnadze's contribution to the end of the Cold War as the Minister of Foreign Affairs of the Soviet Union. The inclusion of Russia meant that the decisions made by the group concerned the whole area surrounding Georgia. As Russia immediately imposed a dominating attitude (renaming the Russian military forces in Abkhazia and South Ossetia as peacekeepers in 1994 marked the first time in the UN practice when the peacekeepers came from a neighbouring country) (Alatalu, 2011b, pp. 185-186), the specialists did not find it surprising that the EU decided to leave Georgia, Armenia and Azerbaijan out of the EU Neighbourhood Policy as "they are not situated in Europe" (2003) and then corrected the mistake by including the three South-Caucasian countries again (2004) but holding the discussion of the development of relations together with the problems of Egypt and Lebanon and also giving the recommendations to all five (March 2005) (Alatalu, 2011a, pp. 7, 11).

The quietude favoured by the great powers in Georgia was ended by the so-called Rose Revolution in November 2003 bringing to power Mikheil Saakashvili armed with US education and promises of finally eliminating the foreign military forces in the country. On November 24, 2004, the first anniversary of the revolution, Saakashvili announced at the UN General Assembly that the elimination of the Russian military bases is a challenge to the current transition to democracy. On March 2005, the Georgian parliament adopted the (fourth) resolution stating that Russia has not carried out the obligations assumed at the OSCE summit in 1999 (to withdraw the military bases in Georgia and Moldova by 2002) and Moscow is dodging at the negotiations, thus demanding the withdrawal of Russian bases by January 1, 2006, that is, three years earlier than Moscow had been ready for it according to the most recent assurances. All this in case Georgia and Russia cannot determine the precise schedule for the withdrawal before May 15. Georgia then defiantly joined the active discussion 
on the world arena about whether to go to Moscow on May 9 or not (see Alatalu, 2010, pp. 23-33).

As already mentioned, the presidents of Estonia and Lithuania announced their non-attendance on March 7, and five days later Saakashvili announced his attendance in case the foreign ministers agree upon the schedule for the withdrawal of the Russian forces by May 6 and the respective joint declaration is signed by the two presidents on May 9 in Moscow (Socor, 2005d). It all had to take place on the Victory Day morning as in the evening Saakashvili was to meet the US president George Bush in Tbilisi. It must be admitted that Moscow had not witnessed such diplomatic and defiant attack for quite a while (which largely explains also the Russian leaders' openly scornful attitude to Saakashvili after the war in 2008 , as so far nobody had dared to treat them in such a manner). The highlanders' tactics clearly also baffled the US and EU leaders. It also baffled the theorists, as the state from the unseen background intruded into the playground of major geostrategic players. As we know, in 1997 the classic theorist of geopolitics Zbigniew Brzezinski distinguished between five Eurasian geostrategic players and five geopolitical pivots-Ukraine, Azerbaijan, South-Korea, Turkey and Iran (Brzezinski, 2003, p. 56). Today we may say that Georgia assumed the leading position in South Caucasus, which theoretically should have belonged to Azerbaijan.

According to Brzezinski (2003, p. 56), the importance of the geopolitical pivot is not "derived from their power and motivation but rather from their sensitive location and from the consequences of their potentially vulnerable condition for the behaviour of geostrategic players." Considering Georgia's vulnerability at the time (and also today), motivation seemed to dominate as the West had not heard such firm desire to join the Euro-Atlantic structures as coming from Georgia in 2003-2004 for a long time. The effect was enhanced by the fact that the civilised world had not witnessed revolutions for a long time and the Rose Revolution was thus greeted with positive sentiments. Saakashvili's prompt decision to rely on the US and NATO soon confirmed the validity of Brzezinski's second postulate - the location of the pivot "gives them a special role in either defining access to important areas or in denying resources to a significant player", as well as the third postulate_- "in some cases a geopolitical pivot may act as a defensive shield for a vital state or even a region" (Brzezinski, 2003) respectively, in relation to and against Russia.

In order to comprehend Georgia's action from March to May 2005, it would be clever to rely on Brzezinski's remarks that out of the five pivots Iran and Turkey are able to be also geostrategically active (Brzezinski, 2003, pp. 56-57), 
whereas geostrategic players are states that have the "power to cause a potentially important shift in the international distribution of power" (Brzezinski, 2003, p. 54). Considering merely the quoted conclusions of the European Council, this is precisely what Saakashvili accomplished. There was also a "geopolitical reorientation" (Grygiel, 2006, p. 23), when considering that Georgia, locating outside the EU, stepped/was placed next to Estonia and Latvia in the relations between EU and Russia and their geographic distance from each other did not obstruct the discussion of their problems together.

In addition, the mutual attraction and communication between the Baltic States and Georgia goes way back in history. They had acted together in 1989-1991, and as Saakashvili admitted that he considered the Baltic practice as his role model, assistance in various spheres followed. At the co-initiative of Estonia (Foreign Ministers Kristiina Ojuland and Salome Zurabishvili) the support group "New Friends of Georgia" joining East-European countries was established on February 4, 2005 as a reaction to the inactivity of the Moscow-minded group "Friends of Georgia" (see above) (Socor, 2005a). Georgian leaders regarded highly the activities of the group (which is active also at present) and considered it also worth mentioning in the national security concepts adopted on July 7 , 2005 (Alatalu, 2012b, pp. 35-37).

The connections between the Georgian and Baltic efforts were stressed also by the US president George Bush. At the height of the events on March 23, it was announced that during his European tour, the US president would visit Riga on May 6-7 (previously also Tallinn had been considered) and Tbilisi on May 9-10. In the meantime, Bush would be in Moscow where the Victory Day celebrations would not be attended by the presidents of Estonia and Lithuania (whom Bush would meet in Riga) and possibly also by the president of Georgia. The Kremlin's situation became more than tense and despite the preparations for celebrating the anniversary of its military victory, the sentiments of the time are well reflected in president Putin's unexpected statement at the State Duma on April 24: the break-up of the Soviet Union was the "greatest geopolitical disaster" of the $20^{\text {th }}$ century. In other words, also in the Kremlin, the situation was assessed in geopolitical categories and the political vocabulary was introduced the phenomenon of loss, an act of injustice inflicted on Russia. Understandably, new defeats had to be avoided.

Two days later it was decided to withdraw from the border treaty with Latvia, which in terms of the present rhetoric could have stood for a loss. It is worth mentioning that Russia ended the border treaty process with marked calmness and on May 6 the Russian Ambassador suggested that the process be opened 
again with the compilation of a joint declaration. This was clearly intended to be a message to the EU-Russian summit on May 10, where the idea of the gradual border treaty process (first the signatures, one day also the ratification) was established, and reflected also in the European Council document.

Various methods were attempted with Tbilisi, the Minister of Defence Sergei Ivanov made an verbal assurance of withdrawing the military bases, however, no agreement was reached at the talks between the Foreign Ministers on May 6 and Saakashvili was not in Moscow three days later. In the meantime, the Georgian parliament had stated that they would also claim for the "damages caused by the occupation", thus raising a historically sensitive subject for Moscow.

President George Bush solved the delicate situation for the US politics by recalling in his speech given on May 10 in the Tbilisi central square the Soviet violence in 1989, but ignoring the topic of Russian military bases and insisting on the "peaceful resolution of conflict" in "sovereign and free" Georgia. What the president failed to mention was compensated by the US Senate resolution of May 12-Russia must withdraw its forces from Georgia (Alatalu, 2009, pp. 120-121). As according to the resolution passed by the Georgian parliament, the Russian forces were threatened by the 'illegal' status and obligation to operate under a "regime of departure", it was decided by Moscow to take a step backwards and on May 13, the Foreign Minister Salome Zurabishvili informed of receiving new suggestions from Moscow with an agreement to continue the talks on May 23 (Anjaparidze, 2005). A week later, on May 30, in Moscow, Zurabishvili and Lavrov signed a joint statement on "completing the closure" of the Russian military bases and the withdrawal of the heavy hardware. As expected, Moscow immediately turned to the typical behaviour of circumvention and non-compliance, but the victory of the small state Georgia was evident.

Tbilisi's success lay undoubtedly in the speed of developing the events and in the fact that the problem remained largely bilateral (the only so-called external statement was made by the US Senate), differently from the border treaties with Latvia and Estonia that were repeatedly discussed or at least mentioned at several multilateral meetings. On the other hand, it was clear that the long-term focussing of world politics on May 9 (2005) and on Moscow placed the Kremlin in a position where it - under the attentive gazes and building new relations with Asia-US-Europe - could merely develop the urge to be generous. After all, Stalin was born in Georgia and it was clear that the promises made applied only to the so-called authentic Georgia and did not include the bases located on the territories governed by separatists. 
In order to fully comprehend the meaning of the concessions to the Kremlin leaders, let us consider the poll results conducted among Russians in May 2005. According to the authoritative research centre VCIOM, 55\% of the people interviewed opposed the closure of the military bases located abroad and only $6 \%$ considered them unnecessary, $50 \%$ of the people considered it important to put pressure on the neighbouring countries, $42 \%$ agreed to the development of dialogues, $31 \%$ supported imposing economic sanctions and $9 \%$ of political sanctions, 11\% supported military intervention (Cameron \& Domanski, 2005, p. 19).

There is no information on whether Russian military bases in Georgia were discussed at the EU-Russia summit on May 10. The press conference at the end of the summit in the Kremlin is memorable for the question or message by Astrid Kannel about the lack of territorial claims by Estonia and the suggestion to apologise for the occupation, to which Vladimir Putin answered by making a clear distinction between the present situation of the border treaties with Estonia and Latvia. As to Latvia, he assured that Moscow is continually willing to sign the agreement, however, without the "idiotic territorial claims". Putin said there are "no problems with Estonia, thank goodness", adding that when he (as an official to the mayor of Leningrad Anatoli Sobchak) participated in the talks between Leningrad and Estonia in 1990 and similar (border) problems emerged, "to the Estonians' honour, they took a pragmatic approach to their national interests". It was followed by criticism on the Estonian President's decision not to come to Moscow, but also by an assurance, "I have instructed our Foreign Ministry to sign this treaty with Estonia" (President of Russia, 2005). The frank reminiscence of his meeting with Estonian politicians (Savisaar, 2004, p. 293) provides a key to understanding the Kremlin's expectations of the behaviour of Estonia with relation to the border treaty as the abovementioned pragmatists, that is, at least Edgar Savisaar was back in the government. The vision of Estonian politicians established in the West was upheld by the carefully-worded statements made by the Prime Minister Andrus Ansip and Foreign Minister Urmas Paet within the limits of the competent institutions (government, Ministry of Foreign Affairs) on the days and weeks preceding the signing of border treaties. It seems that the leaders of the authoritative regime still could not imagine that the leaders of the former imperial colony so strictly could hold on to the principle of the separation of powers in their statements.

Dark clouds gathered soon over the border treaty and from an unexpected direction. On May 23, Vladimir Putin visited the editorial board of the newspaper Komsomolskaya Pravda and the president is usually quoted as saying that Latvia shall "get the ears of a dead ass, not the Pytalovo (Abrene) district". In 
fact, Putin also mentioned the signing of the Estonian border treaty- "we did it deliberately". It was obvious that the president took it out on Estonia and Latvia, albeit briefly, as it was not the main concern, almost half of the discussion was spent on analysing the Georgian claim of withdrawing the military bases. "It is not politically beneficial if our neighbours do not want the continuation of our military presence", but it would be "even worse if we made every effort not to allow them to execute their sovereign rights" (Prezident Rossii, 2005). Putin was openly concerned about the basis going over to a "third country". In answer to the journalists' questions about loyal neighbours, Putin analysed the military presence of Russia in Armenia and Tajikistan (Prezident Rossii, 2005).

The unexpected emergence of Georgian bases on the Russian political agenda is also reflected in the State Duma statement "On Attempts at Falsifying History" adopted four days later (although prepared longer before), which in addition to international organisations was also addressed to the parliaments of Poland, Estonia, Latvia, Lithuania and the US, including the criticism of the behaviour of Poland and the Baltic States with the unexpected mention of the visit of the US president to Tbilisi. Next, the Second European Department of the Russian Ministry of Foreign Affairs issued "analytical-informative materials on the counteraction to the anti-Russian action of the Baltic States and Georgia" (O shagakh, 2005).

We may agree to Vadim Kononenkov's conclusions that it is difficult for Moscow to digest the unexpected activity of Poland and the Baltic States in the EU foreign policy and support of Moldova, the Rose Revolution in Georgia and the Orange Revolution in Ukraine (Kononenkov, 2006, p. 81). The immediate study by the PONARS at George Washington University claimed that the withdrawal of the Russian military bases would mean the departure of Georgia from the Russian zone of influence and becoming a foreign country similar to the three Baltic States (Sokov, 2005).

\section{The geopolitical victory requires speed at the expense of others}

In the present author's opinion, the question of the Russian military bases in Georgia unexpectedly became a primary problem for the Russian leaders (driven by militarist sentiments) also in their relations with the European Union. Russia could not do anything to Georgia at the moment as following the joint statement as of May 30, Tbilisi had cancelled the possible sanctions against the Russian bases (e.g., cutting off electricity and water supply, etc.). However, 
they could attack the European Union entering Moscow's "sphere of interest" and as it happened, an interesting process was halfway with one of the EU Member States-Estonia. Thus, the European Council's decision was taken as a geostrategic challenge in Moscow and a response given to the European Union (see Lavrov's interview as of June 27, 2005, above). It was simultaneously a response to the resolution adopted at the Parliamentary Assembly of the Council of Europe on June 22, 2005 asking and receiving dozens of assurances from Russia (e.g., not to consider neighbours as "the near abroad", see above and Council of Europe Parliamentary Assembly, 2005). The extraordinary punishment of Estonia - for the EU attempting to teach Russia a lesson? - was a clear sign that it had nothing to do with the Estonian-Russian border treaty but instead marked the typical need in big politics to teach somebody a lesson at the expense of somebody else.

The sudden and loud nullification of Estonia was mainly caused by the sudden emergence of Georgia with its "sword-wielding diplomacy" (already forgotten in Europe) in the context of Russia's five border treaties and the development of relations with the EU, and it must be stated that Tbilisi was the only one gaining victory over Russia. The well-considered geopolitical and geostrategic constructs of international relations literally could not withstand the highlanders' revolutionary attack, immediately turning Georgia into a geopolitical pivot with the ability to reshape a geographically remote geostrategic field. Apparently, Moscow still does not know the reason why they had yielded so quickly. Especially in such a delicate question to Moscow as the withdrawal of military bases, which did bring about the gratitude of the US and EU, but then again, Tbilisi was even praised. Entering geopolitics as a comet and relating the border treaties to its military bases, Georgia was merely lucky, and Estonia, preferring a smaller scale (not even consulting with Latvia), in other words, avoiding geopolitics, was not. We should have read Brzezinski earlier.

Toomas Alatalu, Ph.D. from Leningrad University for Revolutionary Situation and Its Peculiarities in Latin America (1977). His teaching experience ranges from universities in Estonia to the Universidad Centroamericana (Managua, Nicaragua) and Masaryk University (Brno, Czech Republic). Between 1992 and 2007 he was thrice elected to the Parliament of Estonia and worked in its Foreign Affairs Committee. His main fields of interest are contemporary revolutions, ENP, foreign policy of small countries, geopolitics in the EU/ NATO-Russian relations. His most quoted article thus far is 'Tuva - A State Reawakens', published in Soviet Studies (vol. 44, no. 5, 1992) at the University of Glasgow. 


\section{References}

Alatalu, T. (2009), 'Gruusia konflikt,' [Conflict in Georgia] in Poliitika, riigiteadus, rahvusvahelised suhted, Tallinn: TTÜ Rahvusvaheliste Suhete Instituut, no. 1(10), pp. 97-125.

_ (2011a), 'New Friends of Georgia vs. Friends of Georgia,' in Estonian Foreign Policy Yearbook 2011, Tallinn: Estonian Foreign Policy Institute, pp. 183-208.

- (2011b), 'Baltic region - the Architect of the Eastern Partnership,' Baltic Horizons, Special issue: The Eastern Partnership \& Central Asia, no. 17(114), pp. 7-12.

— (2012a), 'Eesti-Vene piirilepingu lugu 2005,' [The history of Estonia-Russia border agreement, 2005] in Poliitika, riigiteadus, rahvusvahelised suhted, Tallinn: TTÜ Rahvusvaheliste Suhete Instituut, no. 4(13), pp. 3-37.

— (2012b), 'Georgia uued sõbrad vs. Georgia (vanad) sõbrad ehk väikeriikide söakas vastandumine suuriikidele,' [New friends of Georgia vs (old) friends of Georgia or small nations' feisty confrontation to major world powers] in A. Kasekamp, R. Toomla \& K. Tüür (eds.) Maailmast 2012. RSR artiklite kogumik. Festschrift in honour of Toomas Alatalu on his $70^{\text {th }}$ birthday, Tartu: Tartu Ülikooli kirjastus, pp. 13-42.

Anjaparidze, Z. (2005), 'Georgia and Russia March Toward Diplomatic War,' Eurasia Daily Monitor, vol. 2, no. 97, May 18, 2005.

Brzezinski, Z. (2003), Suur malelaud. Ameerika ülemvõim ja geostrateegilised kohustused, Tallinn: Varrak. [Original: Brzezinski, Z. (1997), The Grand Chessboard: American Primacy and Its Geostrategic Imperatives, New York: Basic Books]

Cameron, F. \& Domanski, J. M. (2005), Russian Foreign Policy with Special Reference to Its Western Neighbors, EPC Issue Paper, no. 37, 13 July 2005. Retrieved from http://www.belgium.iom.int/pan-europeandialogue/documents/ Russian-Foreign-....pdf [accessed Oct 2013]

Council of Europe Parliamentary Assembly (2012), The honouring of obligations and commitments by the Russian Federation. Report/Doc.13018, 14 September 2012. Explanatory memorandum by Mr Frunda and Mr Gross, corapporteurs. Retrieved from http://assembly.coe.int/ASP/XRef/X2H-DW-XSL. asp?fileid=19116\&lang=EN [accessed Oct 2013]

Current Latvia (2005), 'Weekly Summary of News in Latvia,' Current Latvia, 15-22 July 2005, Week 30/2005, no. 617.

European Commission (2006), Border Treaty between the Russian Federation and the Republic of Latvia, Information Note. Brussels: European Commission, DG External Policies delegations. 8 June 2006. Retrieved from http://www. europarl.europa.en/meetdocs/2004_2009/documents/fd/d-ru2006061507/dru2006061507en.pdf [accessed Oct 2013] 
European Council (2004), Presidency Conclusions, 17 and 18 June 2004, 10679/2/04 REV2 Concl 2, Brussels: The Council of the European Union, 19 July 2004.

- (2005), Presidency Conclusions, 16 and 17 June 2005, 10255/1/05. REV1 Concl. 2, Brussels: The Council of the European Union, 15 July 2005.

European Council meeting (2005), 2675th Council Meeting, General Affairs and External Relations, 108915/05, Press release, Brussels: Council of the European Union, 18 July 2005. Retrieved from http://europa.eu/rapid/pressReleasesAction. do?reference $=$ PRES/05/178\&format $=$ HT [accessed Oct 2013]

Estonian Review (2005), Estonian Review: July 11-24, 2005, 27 Jul 2005. Tallinn: Estonian Ministry of Foreign Affairs. Retrieved from http:/www.vm.ee/?q=en/ node/3746 [accessed Oct 2013]

Grygiel, J. J. (2006), Great Powers and Political Change, Baltimore: The Johns Hopkins University Press.

Kagge, R. (2005), 'Piirileppe kinnitamine riigikogus lükkub sügisesse,' [Parliament's ratification of border treaty postponed until autumn] Postimees, 19 May 2005.

Kononenkov, V. (2006), “'Normal neighbours' or 'troublemakers'? The Baltic States in the Context of Russian-EU relations," in A. Kasekamp (ed.) The Estonian Foreign Policy Yearbook 2006, Tallinn: Estonian Foreign Policy Institute, pp. 69-84.

Levinsson, C. (2006), 'The Long Shadow of History: Post-Soviet Border Disputes the Case of Estonia, Latvia, Russia,' Partnership for Peace Consortium Quarterly Journal, vol. 5, no. 2, pp. 98-109.

Made, V. (2005), 'Estonian-Russian relations in the context of the international system,' in A. Kasekamp (ed.) The Estonian Foreign Policy Yearbook 2005, Tallinn: Eesti Välispoliitika Instituut, pp. 93-110.

(2006), 'Eesti-Vene piirileping Euroopa Liidu ja Venemaa suhete kontekstis,' [Estonia-Russia border treaty in the context of EU-Russia relations] Acta Societatis Martensis, no. 2, pp. 233-239.

Masaki, H. (2005), "Putin's Diplomatic Victory in Tokio: Regional Perspective on Russia-Japan Relations," The Asia-Pacific Journal: Japan Focus. Retrieved from http://japanfocus.org/-Hisane-MASAKI/2081?rand?1365071218\&type?print\&pr int?1 [accessed Oct 2013]

Nutt, M. (2011), Eesti parlamendi pädevuse kujunemine ja rakendamine välissuhtluses, [Development of Estonian Parliament's competence and its application in foreign relations] Tallinn: TTÜ press, pp. 167-177.

O shagakh (2005), Predprinimaemykh po protivodeistviiu antirossiiskoi liini stran Pribaltiki i Gruzii, Moskva, 14 Jun 2005. Author's personal archives.

Postimees (2005), 'Urmas Paet: Piirilepingu ratifitseerimine on Riigikogu käes,' [Ratification of border treaty in Parliament's court] Postimees, 20 June 2005.

Rostoks, T. (2006), 'The border issue,' in N. Muižnieks (ed.) Latvian-Russian Relations: Domestic and International Dimensions, Riga: LU akademiskais apgads, pp. 131-139. 
President of Russia (2005), 'Press Statement and Responses to Questions Following the Russia-European Union Summit, Great Kremlin Palace, Moscow, 10 May 2005.' Retrieved from http://www.mid.ru/brp_4.nsf/e78a48070f128a7b432569 99005bcbb3/1f66a6a4bb7104dfc325700000218403?OpenDocument [accessed Oct 2013]

Prezident Rossii (2005), "Stenograficheskii otchet o vstreche s tvorcheskim kollektivom gazety 'Komsomolskaya Pravda'," 23 May 2005. Retrieved from http://archive. kremlin.ru/text/appears/2005/05/88557.shtml [accessed Oct 2013]

Riigikogu transcripts (2005), X Riigikogu: Stenogrammid $\left[10^{\text {th }}\right.$ Parliament of Estonia: Transcripts], vol. 4, Tallinn: Riigikogu.

Rikveilis, A. (2008), 'The Interstate border and Latvian-Russian relations: the past as an impediment to bilateral cooperation - Latvia-Russia-X,' in Ž. Ozolina (ed.) Strategic Analysis Commission under the Auspices of the President of the Republic of Latvia, Riga: Zinātne, pp. 284-331.

Rozman, G. (2002), 'A Chance for a Breakthrough in Russo-Japan relations: will the logic of great power relations prevail,' The Pacific Review, vol. 15, no. 3, pp. 325-357.

Russian MFA (2005), Russian MFA Information and Press Department Commentary Regarding a Media Question Concerning the New Linkage Being Put Forward by the Latvian Side to the Signing of a State Border Treaty, Moscow: Russian Ministry of Foreign Affairs, no. 858-28-04-2005. Retrieved from http://www. mid.ru/Brp_4.nsf/arh/55853F26E6F04105C3256FF10055E841?OpenDocument [accessed Oct 2013]

Savisaar, E. (2004), Peaminister. Eesti lähiajalugu 1990-92, [Prime Minister: Estonia’s Recent History, 1990-92] Tallinn: Kleio.

Sildam, T. (2005), 'Vene parlamendipoliitik: okupatsiooni ei olnud,' [Russian MP: There was no occupation] Postimees, 1 November 2005.

Socor, V. (2005a), 'New group of Georgia's Friends founded,' Eurasia Daily Monitor, vol. 2, no. 26, 7 Feb 2005.

_ (2005b), 'Baltic border agreements on agenda for EU-Russia summit', Eurasia Daily Monitor, vol. 2, no. 85, 2 May 2005.

- (2005c), 'Moscow stonewalling on border agreements with Latvia and Estonia,' Eurasia Daily Monitor, vol. 2, no. 85, 2 May 2005.

(2005d), 'Moscow thwarts joint presidential declaration on troop withdrawal from Georgia,' Eurasia Daily Monitor, vol. 2, no. 90, 9 May 2005.

(2005e), 'Moscow signs border agreement with Estonia,' Eurasia Daily Monitor, vol. 2, no. 99, 20 May 2005.

- (2005f), 'Russia cancels border treaty, assails Estonia,' Eurasia Daily Monitor, vol. 2, no. 127, 30 June 2005. 
Sokov, N. (2005), The Withdrawal of Russian Military Bases from Georgia: Not Solving Anything, PONARS Policy Memo 363, June 2005. Retrieved from http://www. gwu.edu/ ieresgwu/assets/docs/ponars/pm_0363.pdf [accessed Oct 2013]

Takahashi, K. (2005), 'Creative Thinking on the Kurils,' Asian Times Online, 20 April 2005. Retrieved from http://www.atimes.com/atimes/Japan/GD20Dh03.html [accessed Oct 2013]

The Baltic Times (2005), 'Ministry issues draft on relations with Russia,' The Baltic Times, 17-21 February 2005.

Turmanidze, T. (2009), Buffer States: Power policies, Foreign Policies and Concepts, Global Political Studies Series, New York: Nova Science Publishers. 